\title{
ВІДГОДІВЕЛЬНІ ТА ЗАБІЙНІ ЯКОСТІ СВИНЕЙ ІРЛАНДСЬКОГО ПОХОДЖЕННЯ 3А РІЗНОÏ ІНТЕНСИВНОСТІ РОСТУ НА ВІДГОДІВЛІ
}

\author{
Михалко Олександр Григорович \\ аспірант спец. 204 ТВППТ \\ Сумський національний аграрний університет \\ ORCID: 0000-0002-0736-2296/ G-2305-2018 \\ Email: snau.cz@ukr.net
}

Повод Микола Григорович

доктор сільськогосподарських наук, професор

Сумський національний аграрний університет ORCID: 0000-0001-9272-9672/ W-1565-2018

Email: nic.pov@ukr.net

Плечко Оксана Сергіївна

студентка біолого-технологічного факультету Сумський національний аграрний університет

ORCID: 0000-0002-8217-3014

Email: civdef@ukr.net

Кохана Олена Дмитрівна

студентка біолого-технологічного факультету

Сумський національний аграрний університет

ORCID:0000-0002-5388-6082

Email: olena.kohana@ukr.net

Вивчався вплив інтенсивності росту в період відгодівлі та передзабійної живої маси на забійні показники туш. Встановлено, що по завершенню відгодівлі свині дослідної групи за рахунок вищої інтенсивності росту в період відгодівлі досягли передзабійної живої маси в віці 183 доби - 128,48 ке, вірогідно перевищивщи при цьому свиней з низькою інтенсивністю росту, які в тому ж віці мали на 18,84 ке або 14,66\% (p<0,001) нижчу масу. Це спричинено вірогідно вищою інтенсивністтю росту, яка характеризувалась вищим на 16,81 ке або 16,49\% - показником абсолюного приросту (p<0,001), на 158,62 г або 16,50\% - показником середньодобового приросту ( $p<0,001)$, та на 4,54\% - показником відносного приросту (p<0,001), що призвело до більш раннього на 17,52 доби досягнення живої маси в 100 кг. За комплексом відгодівельних якостей, свині з високою інтенсивністю росту переважали аналогів з низькою на 13,00 балів або 32,22\%. Свині з вищою інтенсивністю росту в період відгодівлі, які були забиті за передзабійної живої маси в 130 кг, достовірно переважали своїх аналогів, яких забивали за ваги в 110 кг за показниками: забійної маси на 14,4 кг або 15,06\%, маси охолодженої туші на 14,2 ке або 15,15\%, товщиною шпику над 6-7 грудним хребцями на 4,01 мм або 11,43\%, товщиною шпику в холці на 3,7 мм або 8,89\%, товщиною шпику в крижах на 3,0 мм або 9,09\%, довжиною туші на 3,7 см або 3,64\%,довжиною беконної половинки на 6,4 см або 7,18\%, масою окосту на 2,5 ке або 16,18\%, масою балику на 0,6 ке або 16,90\% та площею «м'язового вічка» на 5,2 см² або 7,21\%. Не встановлено вірогідної різниці у величині втрат маси під час охолодження між тушами тварин обох груп. Шляхом однофакторного дисперсійного аналізу встановлено достовірний вплив показника передзабійної живої маси свиней на довжину туші - на 44,13\%, на довжину беконної половинки - на 42,52\%, на товщину шпику: в крижах - на 83,24\%, над 6-7 хребцями - на 82,81\%, в холиі - на 84,04\%, на масу окосту - на 67,14\%, на площу «м'язового вічка» - на рівні 88,12\%. Комплексний індекс відгодівельних і м'ясних якостей виявився вищим у свиней із середньою забійною вагою в 130 ке, склавши 188,01 балів, що вище на 10,76 або 5,72\%, ніж у свиней, чия середня забійна вага досягала 110 ке. Доведено, що на кожне збільшення товщини шпику в холиі за передзабійної живої маси 110 кг на 1,0 мм площа «м'язового вічка» туш дослідних тварин також пропориійно збільшиться на 3,01 см² Встановлений прямий зв'язок між показниками товщини шпику у холці та площею «м'язового вічка» для туш за передзабійної живої маси 110 кг дозволяє зробити припущення, що існує резерв підвищення передзабійної живої маси як за рахунок збільшення жирових тканин, так і за рахунок одночасного збільшення кількості м'язових тканин. Однак, існує певна оптимальна вагова межа між забійною масою 110 та 130 ке, за якою розподіл залежності стає зворотнім і подальша відгодівля та збільшення кількості жиру призведе до пониження показників м'ясних якостей туш, що є економічно недоцільним.

Ключові слова: свині, забійна маса, товщина шпику, довжина туші, маса окосту, площа «м'язового вічка», інтенсивність росту

DOI: https://doi.org/10.32845/bsnau.Ivst.2020.4.8

У висококонкурентному свинарстві підвищена ефективність виробництва часто $є$ єдиним інструментом вижи-

вання підприємства, доступним виробнику. Висока ефективність може бути досягнута різними способами, серед яких, 
показник підвищеної забійної ваги, який має резерви додаткового дослідження та подальшого результативного застосування.

Відгодівля свиней до різної передзабійної живої маси у будь-якому випадку має на меті отримання найвищої економічної ефективності виробництва свинини, однак вимагає урахування не тільки виробничих витрат, але і споживчих настроїв та конь'юктури як внутрішніх, так і зовнішніх ринків збуту, що ставить особливі вимоги до забійних якостей свиней.

Оптимальна маса забою була визначена різними авторами. Деякі з них [13] визначили оптимальну забійну вагу свиней в цілому, як вагу, при якій досягається запас прибутку між витратами на вирощування однієї голови та обробку туші, з одного боку, і вартістю реалізованої свинини з іншого боку. Інші дослідники стверджують, що оптимальна забійна вага становить взаємозв'язок між живою вагою, ефективністю корму та нежирним м'ясним вмістом забійного виходу, який значною мірою залежить від потенціалу м'якої тканини для росту тварини, яка в свою чергу, визначається генотипом і статтю [14].

Дослідження сучасних авторів свідчать про збільшення забійного виходу, товщини шпику, довжини туші, маси ії задньої третини та площі «м'язового вічка», всіх морфометричних показників туш у свиней при забої за більш важких кондицій [6].

За результатами останніх проведених експериментів [3] спостерігалася пряма залежність між середньодобовими приростами свиней на відгодівлі та індексом м'ясності. 3більшення площі «м'язового вічка» в групах тварин, вирощених із вищими середньодобовими приростами, вело до збільшення індексу м'ясності.

Дослідженнями вітчизняних авторів доведено, що із підвищенням передзабійної живої маси свиней за різних типів утримання у їхніх тушах знижується вміст м'яса і кісток та збільшується вміст сала. Таким чином, потенціал відгодівельної продуктивності, спричинений кращими умовам утримання при підвищенні забійної маси частково нівелюється [10].

Згідно висновків деяких авторів, втрати маси при транспортуванні та втрати маси при охолодженні виявились вищими у свиней за передзабійної живої маси в 120 кг порівняно із тваринами з передзабійною живою масою в 100 кг [11].

Результати багатьох досліджень показують, що кращими забійними якостями відрізняються свині ірландського походження за передзабійної живої маси в 120 кг порівняно з аналогами вітчизняного походження за довжиною півтуші, товщиною шпику, масою задньої третини напівтуші та площею «м'язового вічка» [7].

За раніше встановленими даними [8], збільшення передзабійної живої маси спричинене підвищеною інтенсивністю росту, сприяє збільшенню забійного виходу та довжини туші, але призводить до підвищення відкладання підшкірного сала, що погіршує м'ясність.

Інтенсивна годівля свиней на початку відгодівлі та подальше помірне споживання корму наприкінці сприяє формуванню туш з підвищеним виходом м'яса при забої за досягнення маси в 100 кг [1], а подальша відгодівля до передзабійної маси в 120 кг може призводити лише до збільшення частки сала у забійному виході [4]. Ця думка підтвер- джує висновок, що утримання свиней до передзабійної живої маси в 120 кг характеризується зниженням інтенсивності росту тварин та погіршенням конверсії корму i, як наслідок, зниженням економічної ефективності виробництва свинини [11].

За результатами вивчення впливу передзабійної живої маси на відгодівельні та забійні якості свиней зі збільшенням живої ваги свиней до 125 кг спостерігалося значне збільшення маси парної туші та відсотка забійного виходу (р $<0,05)$. Однак, не було виявлено доказів того, що збільшення маси забою погіршує характеристики туші або якість м'яса [12].

За даними іноземних авторів збільшення товарної ваги до 130 кг вплинуло на загальну інтенсивність росту свиней негативно. Зокрема, сукупний середньодобовий приріст зменшився на 4,0 г, середньодобове споживання корму зросло на 78,1 г, а відносний приріст зменшився на 0,011 на кожні 10 кг збільшення забійної ваги [16].

Згідно висновків альтернативних досліджень, із збільшенням забійної ваги на кожні 10 кг збільшувався забійний вихід туші на 0,41\%, середня товщина шпику на 1,8 мм, площа «м'язового вічка» на $1,9 \mathrm{~cm}^{2}$, довжина туші на 2,2 cм, але зменшувався відсоток нежирних напівфабрикатів на 0,78\% взагалі, в тому числі корейки, плеча та шинки на 0,13 , 0,16 та 0,17\% відповідно [15]

Проведений аналіз робіт зарубіжних авторів щодо впливу забійної ваги на якість свинини виявив середню динаміку зниження рН на 0,02 та 0,01 через 45 хв. і 24 години після смерті, але одночасно і зростання його значення на 0,28 зі зростанням забійної ваги відповідно на кожні 10 кг понад масу в 100 кг [17].

Таким чином, недостатньо вивчений вплив передзабійної живої маси свиней на їх відгодівельні та забійні якості набуває тільки більшої актуальності щодо подальших досліджень з урахуванням наявних резервів реалізації генетичного потенціалу м'ясності тварин ірландського походження.

Метою роботи $€$ виявлення впливу передзабійної живої маси відгодівельного молодняку свиней на зміну показників відгодівельних та забійних якостей для подальшого підвищення ефективності виробництва свинини.

Матеріали та методи досліджень. Для досягнення поставленої мети нами було проведено дослідження по вивченню впливу швидкості росту відгодівельних свиней на їх забійні якості на базі цеху відгодівлі №3 «НВП «Глобинський свинокомплекс». При постановці на відгодівлю по досягненні віку 70 діб із піддослідних тварин сформували групу з 400 голів з рівною кількістю кнурців і свинок, яких індивідуально зважили та помітили бирками з індивідуальними номерами. На відгодівлі їх утримували по 50 голів в ідентичних умовах у станках по 40м ${ }^{2}$ кожний, на повністю щілинній бетонній підлозі. Годівля здійснювалась 8-10 разів на добу відповідно до кривої годівлі, рідкими повнораціонними кормосумішами в співвідношенні сухого корму до рідкої фракції 1 : 3 за допомогою обладнання австрійської фірми Weda. При досягненні середньої маси близької до 120 кг тварин індивідуально зважували та наносили спреєм отриману вагу на спині тварини. За результатами цього зважування відбирали по 60 голів для контрольного забою живою масою 110 та 130 кг. На базі Глобинського м'ясокомбінату після 24 годинної голодної витримки, тварин з кожної групи повторно 
зважували і проводили контрольний забій з обвалюванням туш за загальноприйнятою методикою [5]. Після забою туші зважували, потім охолоджували впродовж 24 годин при температурі від 2 до - 4 으.

При забої враховували наступні показники: передзабійну живу масу; забійну масу; забійний вихід; довжину туші та беконної її половинки; товщину шпику разом із товщиною шкіри у трьох точках вимірювання (на холці, над остистими відростками між шостим і сьомим грудними хребцями, на крижах). Після відділення задньої третини туші зважували масу обох окостів. По завершенню обваловування середньої частині туші визначали масу балику та площу «м'язового вічка».

За результатами дослідження було розраховано індекс відгодівельних якостей за формулою М.Д. Березовського [2]:

$$
\mathrm{I}=\mathrm{A}^{2} /(\mathrm{B} \times \mathrm{C})
$$

де: А - валовий приріст за період відгодівлі, кг; В - кількість діб відгодівлі, днів;
C - витрати корму на 1 кг приросту, кг.

Також було розраховано комплексний індекс відгодівельних і м'ясних якостей, що має таку структуру [2]: $\mathrm{I}=100+(242 \times K)-(4,13 \times \mathrm{L})$,

де: । - комплексний індекс відгодівельних і м'ясних якостей;

К - середньодобовий приріст, кг;

$L$ - товщина шпику на рівні 6-7 грудних хре-

бців, мм;

242 та 4,13 - постійні коесріцієнти.

Отримані результати досліду були обраховані біометрично за допомогою прикладних програм Microsoft Office Excel.

Також, з метою визначення сили впливу перед забійної маси тварин на деякі забійні показники було проведено однофакторний дисперсійний аналіз.

Результати досліджень (табл. 1) показують різні значення показників відгодівельних якостей тварин обох піддослідних груп.

Таблиця 1

Відгодівельні показники свиней за різної передзабійної живої маси, (n=60)

\begin{tabular}{|c|c|c|}
\hline \multirow{2}{*}{ Показник } & \multicolumn{2}{|c|}{ Забійна вага } \\
\hline & I контрольна група (110 кг) & II дослідна група (130 кг) \\
\hline Середня маса при постановці на відгодівлю, кг & $26,0 \pm 0,20$ & $26,5 \pm 0,33$ \\
\hline Середня маса при знятті з відгодівлі, кг & $109,64 \pm 0,40$ & $128,48 \pm 0,43^{* * *}$ \\
\hline Кількість днів на відгодівлі, діб & 106 & 106 \\
\hline Абсолютний приріст, кг & $85,12 \pm 0,46$ & $101,93 \pm 0,43^{\star * *}$ \\
\hline Середньодобовий приріст, г & $802,99 \pm 4,31$ & $961,61 \pm 4,04^{* * *}$ \\
\hline Відносний приріст, \% & $127,07 \pm 0,78$ & $131,61 \pm 0,44^{\star * *}$ \\
\hline Вік досягнення маси 100 кг, діб & $165,9 \pm 0,86^{* * *}$ & $148,38 \pm 0,92$ \\
\hline Індекс відгодівельних якостей, балів & 27,35 & 40,35 \\
\hline
\end{tabular}
Примітки: ${ }^{*} P>0,95 ;{ }^{* *} P>0,99$

Тварини, поставлені на відгодівлю, не відрізнялись за показником середньої живої маси, проте, по завершенню процесу відгодівлі свині дослідної групи за рахунок вищої інтенсивності росту досягли передзабійної живої мас у віці 183 доби 128,48 кг, вірогідно перевищивши при цьому однолітків контрольної групи, які в тому ж віці мали на 18,84 кг або 14,66\% (p<0,001) нижчу масу і набрали лише 109,64 кг. Це спричинено вірогідно вищою інтенсивністтю їх росту, яка характеризувалась вищим на 16,81 кг або 16,49\% показником абсолюного приросту ( $<<0,001)$, на 158,62 г або $16,50 \%$ - показником середньодобового приросту ( $<<0,001)$, та на $4,54 \%$ - показником відносного приросту ( $<<0,001)$.
Цей фрактор спричинив більш раннє на 17,52 доби досягнення живої маси в 100 кг свиньми дослідної групи в порівнянні з їх аналогами із контрольної.

За комплексом відгодівельних якостей, розрахованих з допомогою оціночного індексу, свині, які досягали передзабійної живої маси в 130 кг переважали аналогів, що мали забійну масу в 110 кг на 13,00 балів або 32,22\%.

Свині дослідної групи, які мали вищу інтенсивність росту в період відгодівлі і були забиті за передзабійної живої маси в 130 кг достовірно переважали своїх аналогів, яких забивали за ваги в 110 кг за показником збійної маси на 14,4 кг або 15,06\% (табл. 2).

Таблиця 2

Забійні показники свиней за різної передзабійної живої маси, (n=60)

\begin{tabular}{|l|c|c|}
\hline \multicolumn{1}{|c|}{ Показник } & \multicolumn{2}{c|}{ Забійна вага } \\
\cline { 2 - 3 } & І контрольна група (110 кг) & II дослідна група (130 кг) \\
\hline Середня передзабійна жива маса, кг & $109,64 \pm 0,40$ & $128,48 \pm 0,43^{* * *}$ \\
\hline Забійна маса, кг & $81,2 \pm 0,83$ & $95,6 \pm 1,02^{* * *}$ \\
\hline Забійний вихід, \% & 74 & 74,4 \\
\hline Маса охолодженої туші, кг & $79,5 \pm 0,68$ & $93,7 \pm 0,65^{\star * *}$ \\
\hline Втрати при охолоджені, кг & $1,7 \pm 0,22$ & $1,9 \pm 0,19$ \\
\hline Втрати при охолоджені, \% & $2,13 \pm 0,24$ & $2,02 \pm 0,23$ \\
\hline Товщина шпику, см: & & \\
\hline над 6-7 грудним хребцем, мм & $31,1 \pm 0,13$ & $35,0 \pm 0,15^{*}$ \\
\hline в крижах, мм & $30,1 \pm 0,19$ & $33,1 \pm 0,12$ \\
\hline в холці, мм & $41,3 \pm 0,15$ & $45,0 \pm 0,10^{*}$ \\
\hline Середнє значення трьох промірів & $34,0 \pm 0,14$ & $37,6 \pm 0,11^{*}$ \\
\hline Довжина туші, см & $98,0 \pm 0,89$ & $101,7 \pm 0,79^{* *}$ \\
\hline Довжина беконної половинки, см & $82,7 \pm 0,75$ & $89,1 \pm 0,64^{* * *}$ \\
\hline Маса окосту, кг: & & \\
\hline
\end{tabular}




\begin{tabular}{|c|c|c|}
\hline \multirow{2}{*}{ Показник } & \multicolumn{2}{|c|}{ Забійна вага } \\
\hline & І контрольна група (110 кг) & II дослідна група (130 кг) \\
\hline правого & $12,9 \pm 0,21$ & $15,5 \pm 0,20^{\star * *}$ \\
\hline лівого & $13,0 \pm 0,22$ & $15,4 \pm 0,29^{* * *}$ \\
\hline середнє значення & $12,95 \pm 0,25$ & $15,45 \pm 0,27^{* \star *}$ \\
\hline Площа «м'язового вічка», см² & $66,9 \pm 2,33$ & $72,1 \pm 2,13$ \\
\hline \multicolumn{3}{|l|}{ Маса балику, кг } \\
\hline правого & $3,0 \pm 0,08$ & $3,5 \pm 0,09^{* * *}$ \\
\hline лівого & $2,9 \pm 0,09$ & $3,6 \pm 0,06^{* * *}$ \\
\hline середнє значення & $2,95 \pm 0,07$ & $3,55 \pm 0,07^{* * *}$ \\
\hline Комплексний індекс відгодівельних і м'ясних якостей & 177,27 & 188,01 \\
\hline
\end{tabular}

Середня маса охолодженої туші свиней II (дослідної групи) зафіксована на рівні 93,7 кг, тоді як в I (контрольної) на рівні 79,5 кг, що на 14,2 кг або 15,15\% достовірно $(p<0,001)$ вище в порівнянні з контрольною. Однак, не було встановлено вірогідної різниці у величині втрат маси під час охолодження між тушами тварин обох груп.

В той же час необхідно відмітити, що за товщиною шпику над 6-7 грудним хребцями та товщиною шпику в холці переважали тварини, що завершили відгодівлю за маси в 130 кг достовірно на 4,01 мм або 11,43\% (p<0,001) та на 3,7 мм або 8,89\% відповідно порівняно з однолітками, знятими 3 відгодівлі за маси в 110 кг. Також туші свиней дослідної групи мали тенденцію до перевищення аналогів з контрольної за товщиною шпику в крижах на 3,0 мм або на 9,09\%.

Довжина туші та довжина беконної половинки були вірогідно більшими у тушах 130-ти кг тварин на $3,7 \mathrm{~cm}$ $(p<0,01)$ та 6,4 cм $(p<0,001)$ або на 3,64\% та 7,18\% відповідно ніж у тушах 110-ти кілограмових аналогів.

За показниками забою свині контрольної групи, які мали нижчу інтенсивність росту під час відгодівлі, в порівнянні $з$ тваринами дослідної групи з вищою інтенсивністю росту відрізнялись вищим на 2,5 кг або 16,18\% (р<0,001) середнім значенням показника маси окосту в тушах так і вищим на 0,6 кг або $16,90 \%(p<0,001)$ середнім значенням маси балику.

Також свині відгодовані до 130-кг перед забійної живої маси мали тенденцію до перевищення за показником площі «м'язового вічка» на 5,2 см² або 7,21\%, над тваринами досягнувшими за цей час 110-ти кілограмової передза-

\section{бійної живої маси}

Комплексний індекс відгодівельних і м'ясних якостей виявився вищим у свиней із середньою забійною вагою в 130 кг, склавши 188,01 балів, що вище на 10,76 або 5,72\%, ніж у свиней, чия середня забійна вага досягала 110 кг.

Шляхом однофакторного дисперсійного аналізу визначали силу впливу фрактора середньої передзабійної живої маси на забійні показники свиней (рис. 1).

Таким чином було встановлено достовірний вплив

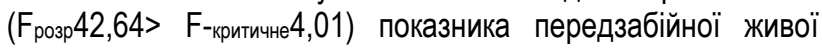
маси свиней на довжину туші на $44,13 \%$. В той же час дія неврахованих факторів спричинила зміну вказаного показника на $55,87 \%$.

Результати впливу передзабійної маси на довжину беконної половинки виявилися статистично достовірними і спричиняли зміну її значень в межах 42,52\% ( $F_{\text {розр }} 39,98>\mathrm{F}$ критичне 4,01).

Однофакторний дисперсійний аналіз виявив достовірний вплив фракторної ознаки і на товщину шпику: в крижах на $83,24 \%$ ( $F_{\text {розр }} 10,87>\mathrm{F}$-критичне4,01), в області 6-7 хребця на $82,81 \%$ ( $\mathrm{F}_{\text {розр }} 11,21>\mathrm{F}$-критинне 4,01$)$, в холці - на $84,04 \%$

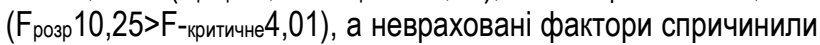
ії коливання на $16,76 \%, 17,19 \%$ та 15,96\% відповідно.

Як вага окосту, так і вага балику вірогідно залежали від передзабійної живої маси тварин на $67,14 \%$ $\left(F_{\text {розр }} 110,36>F_{\text {-критичне }} 4,01\right) \quad$ і $\quad$ на $59,94 \% \quad\left(F_{\text {розр }} 36,08>F-\right.$ критичне 4,01 ), а решта змін ваги напівфабрикатів відбулась під дією неврахованих фракторів співставно на $32,86 \%$ та на $40,06 \%$.

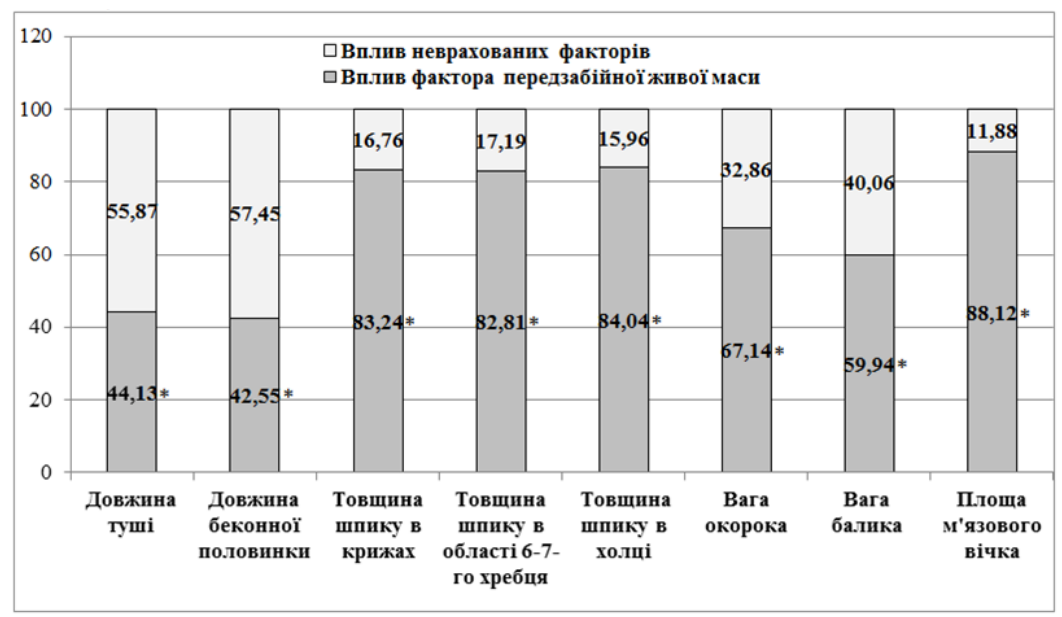

Рис.1. Сила впливу фактору передзабійної живої маси на морфометричні показники туш

Підтверджена вірогідна залежність показника площі «м'язового вічка» від живої передзабійної маси поголів'я на рівні $88,12 \%\left(\mathrm{~F}_{\text {розр }} 7,27>\mathrm{F}_{\text {-критинне }} 4,01\right)$, при чому інші фрактори впливали на формування значення площі лише на $11,88 \%$. 
Шляхом побудови двовимірної лінійної математичної моделі за методом найменших квадратів (табл. 3) проведено аналіз наявності і тісноти лінійної залежності між показниками товщини шпику в холці та площі м'язового вічка свиней, забитих за живої маси в 130 кг, через визначення коефіцієнта парної кореляції, який показав, хоча і слабкий $\left(0,1<r_{x y 130}<0,3\right)$, але зворотній $\left(r_{x, y 130<0)}\right.$ та статистичнозначущий $\left(F_{\text {розр130 }}>F_{\text {крит130 }}\right)$ зв'язок між ними для даної групи. А це свідчить, що із зростанням товщини шпику в холці зменшується площа «м'язового вічка».

В той же час залежність між товщиною шпику в холці та площею «м'язового вічка» тварин, забитих за живої маси

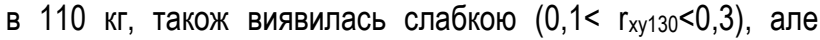
навпаки, прямою $\left(r_{x, y 110}>0\right)$ і статистично достовірною $\left(F_{\text {розр110 }}>F_{\text {крит110 }}\right)$. Прямий зв'язок між показниками свідчить, що при досягненні середньої живої маси в 110 кг свині ще можуть набирати вагу за рахунок збільшення товщини шпику без погіршення показників м'ясності.

Таблиця 3

Статистичні дані двовимірної лінійної математичної моделі за методом найменших квадратів

\begin{tabular}{|l|c|c|}
\hline \multicolumn{1}{|c|}{ Показники } & І контрольна група (130 кг) & ІІ дослідна група (110 кг) \\
\hline F критичне, $F_{\text {крит }}$ & 0,4697 & 0,0377 \\
\hline Коефіцієнт парної кореляції, $r_{x, y}$ & $-0,1424$ & 0,1633 \\
\hline Розрахункове значення критерію Фішера, $F_{\text {розр }}$ & 0,5382 & 4,7763 \\
\hline Коефіцієнт детермінації, $R^{2}$ & 0,0203 & 0,0267 \\
\hline
\end{tabular}

Оцінка коефіцієнта детермінації за встановленої зворотної залежності, показує, що 2,03\% дисперсії результативної ознаки площі «м'язового вічка» обумовлено зміною факторної ознаки товщини шпику в холці для свиней з передзабійною живою масою в 130 кг, а решта - впливом випадкових чинників (рис. 2).

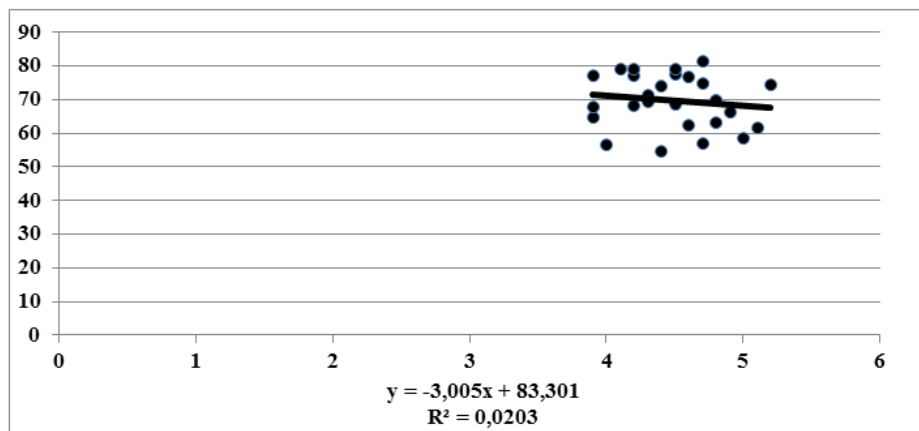

Рис.2. Лінійна апроксимація залежності площа «м'язового вічка» від товщини шпику в холці за передзабійної живої маси 130 кг

Коесріцієнт рівняння зворотної лінійної регресії показує, що на кожне збільшення товщини шпику в холці за передзабійної живої маси 130 кг на 1,0 мм площа «м'язового вічка» пропорційно зменшиться на 3,005 мм (рис. 2).

Оцінка коефріцієнта детермінації за встановленої прямої залежності, показує, що зміна площі «м'язового вічка» обумовлена зміною показника товщини шпику в холці для свиней з передзабійною живою масою в 110 кг не більше ніж на 2,67\%, а решта спричинена впливом випадкових показників (рис. 3).

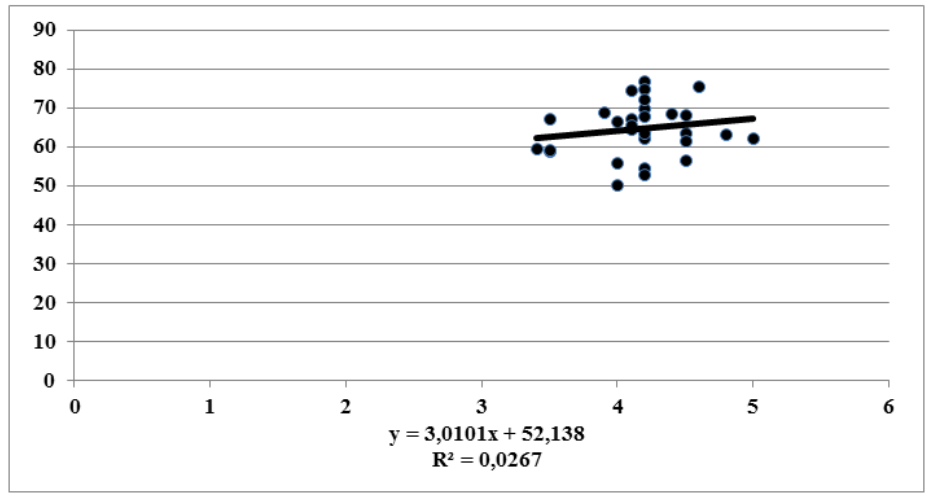

Рис.3. Лінійна апроксимація залежності площа «м'язового вічка» від товщини шпику в холці за передзабійної живої маси 130 кг

Параметри рівняння прямої лінійної регресії показують, що на кожне збільшення товщини шпику в холці за передзабійної живої маси 110 кг на 1,0 мм площа «м'язового вічка» туш дослідних тварин також пропорційно збільшиться на 3,01 $\mathrm{cm}^{2}$ (рис. 3).

Встановлений прямий зв'язок між показниками товщини шпику у холці та площею «м'язового вічка» для туш за передзабійної живої маси 110 кг дозволяє зробити припу- щення, що існує резерв підвищення передзабійної живої маси як за рахунок збільшення жирових тканин, так і за рахунок одночасного збільшення кількості м'язових тканин. Однак, існує певна оптимальна вагова межа між забійною масою 110 та 130 кг, за якою розподіл залежності стає зворотнім і подальша відгодівля та збільшення кількості жиру призведе до пониження показників м'ясних якостей туш, що $€$ економічно недоцільним. 
Висновки. Свині з вищою інтенсивністю росту в період відгодівлі, які були забиті за передзабійної живої маси в 130 кг, достовірно переважали своїх аналогів, яких забивали за ваги в 110 кг за показниками: забійної маси на 14,4 кг або $15,06 \%$, маси охолодженої туші на 14,2 кг або 15,15\%, товщиною шпику над 6-7 грудним хребцями на 4,01 мм або $11,43 \%$, товщиною шпику в холці на 3,7 мм або 8,89\%, товщиною шпику в крижах на 3,0 мм або 9,09\%, довжиною туші на 3,7 см або 3,64\%, довжиною беконної половинки на 6,4 см або 7,18\%, масою окосту на 2,5 кг або 16,18\%, масою балику на 0,6 кг або 16,90\% та площею «м'язового вічка» на $5,2 \mathrm{~cm}^{2}$ або 7,21\%.

Не встановлено вірогідної різниці у величині втрат маси під час охолодження між тушами тварин обох груп.

Шляхом однофакторного дисперсійного аналізу встановлено достовірний вплив показника передзабійної живої маси свиней на довжину туші - на 44,13\%, на довжину беконної половинки - на 42,52\%, на товщину шпику: в крижах - на 83,24\%, над 6-7 хребцями - на 82,81\%, в холці - на $84,04 \%$, на масу окосту - на $67,14 \%$, на площу «м'язового вічка» - на рівні $88,12 \%$.

Доведено, що на кожне збільшення товщини шпику в холці за передзабійної живої маси 110 кг на 1,0 мм площа «м'язового вічка» туш дослідних тварин також пропорційно збільшиться на $3,01 \mathrm{~cm}^{2}$.

Перспективи подальших досліджень. Вважаємо за доцільне провести подальше вивчення залежності між інтенсивністю росту та передзабійними і забійними якостями свиней ірландського походження на відгодівлі з метою пошуку оптимального та економічно-обгрунтованого значення їх передзабійної живої маси.

\section{Список використаної літератури:}

1. Баньковська І. Б., Волощук В. М. Вплив факторів генотипу та способу утримання на морфологічний склад туш свиней. Вісник аграрної науки Причорномор'я. Миколаїв:МНАУ, 2015. Вип. 2(84), Т (2). с. 91-99.

2. Березовский Н. Д., Почерняев Ф. К., Коротков В. А. Методика моделирования индексов для использования их в селекции свиней. Методы улучшения процессов селекции, разведения и воспроизводства свиней (методические указания). М., 1986. с. 3-14.

3. Бірта Г. О., Бургу Ю. Г. Відгодівельні, забійні та м'ясо-сальні якості свиней різних напрямів продуктивності. Вісник Полтавської державної аграрної академії, Серія «Сільське господарство. Тваринниитво», 2012, Вип. 4, с. 49-51.

4. Бірта Г. О. Товарознавча характеристика продукції свинарства. К.: Центр учбової літератури, 2011, с. 144.

5. Коваленко В. А. Методические рекомендации по оценке мясной продукции, качества мяса и подкожного жира свиней. М.: ВАСХНИЛ, 1987, с. 64.

6. Нечмілов В. М., Повод М. Г. Відгодівельна продуктивність свиней за різних термінів дорощування та використання сухого і рідкого типів годівлі. Вісник Сумського національного аграрного університету. Серія «Тваринництво», 2018, Вип. 7 (35), с. 122-134.

7. Повод М. Г., Храмкова О. М. Морфометричні показники туш свиней залежно від генотипу та передзабійної живої маси. Науково-технічний бюлетень IT НААН. Вип. 119, 2018, с. 158-165.

8. Повод М. Г., Самохіна Є. А., Кисельов О. Б. М'ясні та забійні якості свиней різних генотипів за відмінних вагових кондицій. Вісник Сумського національного аграрного університету. Серія «Тваринництво», 2017, Вип. 5 (2), с. $114-118$.

9. Поливода А. М. Стробыкина Р. В., Любецкий Н. Д. Методика оценки качества продуктов убоя свиней. Методики исследований по свиноводству. Харьков, 1977. с. 48-56.

10. Хмельничий Л. М., Вечерка В .В., Шпетний М. Б., Бордунова О. Г., Павленко Ю. М., Опара В. О. Відгодівельні та забійні якості свиней різних вагових категорій дорощених у станках на полімерній та бетонній підлозі. Вісник Сумського національного аграрного університету. Серія «Тваринництво», 2020, Вип. 1 (40), с. 1-9.

11. Храмкова О. М., Повод М. Г. Забійні якості свиней ірландського походження за різної передзабійної живої маси. Вісник Сумського національного аграрного університету. Серія «Тваринниитво», 2018, Вип. 2(34), с. $247-250$.

12. Correa, J. A, Faucitano, L., Laforest, J. P. and Rivest, J., 2006. Effects of slaughter weight on carcass composition and meat quality in pigs of two different growth rates. Meat Science, issue 72(1), pp. 91-99 DOI: 10.1016/j.meatsci.2005.06.006

13. Ellis, M. and Avery, P. J., 1994. The influence of heavy slaughter weights on growth and carcass characteristics of pigs. British Society of Animal Production, issue 5, p. 569

14. Fowler, V. R., Bichard, M., and Pease, A., 1976. Objectives in pig breeding. Animal Production, issue 23, pp. 365-387.

15. Suarez-Belloch, J., M. Sanz, M. Joy, and Latorre, M., 2013. Impact of increasing dietary energy level during the finishing period on growth performance, pork quality and fatty acid profile in heavy pigs. Meat Sci., issue 93, pp. $796-801$. doi:10.1016/j.meatsci.2012.12.006

16. Wu, F., Vierck, K. R., DeRouchey, J. M., O’Quinn, T. G., Tokach, M. D., Goodband, R. D., Dritz, S. S., and Woodworth, J. C., 2017. A review of heavy weight market pigs: status of knowledge and future needs assessment. Anim. Sci., issue 1, pp. 1-15 doi:10.2527/tas2016.0004

17. Zanfi, C. and Spanghero. M., 2012. Digestibility of diets containing whole ear corn silage for heavy pigs. Livestock Science, issue 145, pp. 287-291. dx.doi.org/10.1016/j.livsci.2012.01.009 doi:10.1016/j.livsci.2012.01.009

\section{References:}

1.Bankovs'ka, I. B. and Voloshchuk, V.M., 2015. Vplyv faktoriv henotypu ta sposobu utrymannya na morfolohichnyy sklad tush svyney [Genotype factors and way of animal housing affected on the morphological composition carcasses of pigs]. Visnyk ahrarnoyi nauky Prychornomoriya, issue 2(84), pp. 91-99.

2.Berezovskiy, N.D., Pochernyaev, F.K. and Korotkov, V.A., 1986. Metodika modelirovaniya indeksov dlya ispolzovaniya in v 
selektsii sviney [Methodology for modeling indices for use in breeding pigs]. Metodyi uluchsheniya protsessov selektsii, razvedeniya $i$ vosproizvodstva sviney (metodicheskie ukazaniya), pp. 3-14.

3.Birta, H.O. and Burhu, Yu.H., 2012. Vidhodivelni, zabiini ta miaso-salni yakosti svynei riznykh napriamiv produktyvnosti [Fattening, slaughter and meat and fat qualities of pigs of different directions of productivity]. Visnyk Poltavskoi derzhavnoi ahrarnoi akademii, Seriia «Silske hospodarstvo. Tvarynnytstvo»issue 4, pp. 49-51.

4.Birta, H.O., 2011. Tovaroznavcha kharakterystyka produktsii svynarstva [Commodity characteristics of pig products]. Kiyv.Tsentr uchbovoi literatury, p.144

5.Kovalenko, V.A., 1987. Metodicheskie rekomendatsii po otsenke myasnoy produktsii, kachestva myasa i podkozhnogo zhira sviney [Methodical recommendations for the assessment of meat products, meat quality and subcutaneous fat of pigs]. Moscow. VASHNIL, 1987. p. 64

6.Nechmilov, V.M., and Povod, M.H., 2018. Vidhodivelna produktyvnist svynei za riznykh terminiv doroshchuvannia ta vykorystannia sukhoho i ridkoho typiv hodivli [Fattening productivity of pigs at different terms of rearing and use of dry and liquid types of feeding.]. Visnyk Sumskoho natsionalnoho ahrarnoho universytetu. Seriia «Tvarynnytstvo», issue 7 (35), pp. 122-134.

7. Povod, M.H., Khramkova, O.M., 2018. Morfometrychni pokaznyky tush svynei zalezhno vid henotypu ta peredzabiinoi zhyvoi masy [Morphometric parameters of pig carcasses depending on genotype and pre-slaughter live weight]. Naukovo tekhnichnyi biuleten IT NAAN, issue119, pp.158-165.

8.Povod, M.H., Samokhina, Ye.A. and Kyselov, O.B., 2017. Miasni ta zabiini yakosti svynei riznykh henotypiv za vidminnykh vahovykh kondytsii [Meat and slaughter qualities of pigs of different genotypes at different weight conditions]. Visnyk Sumskoho natsionalnoho ahrarnoho universytetu. Seriia «Tvarynnytstvo», issue 5 (2), pp. 114-118.

9.Polivoda, A.M. Strobyikina, R.V. and Lyubetskiy, N.D., 1977. Metodika otsenki kachestva produktov uboya sviney [Methods for assessing the quality of pig slaughter products]. Metodiki issledovaniy po svinovodstvu. Harkov, pp. 48-56.

10. Khmelnychyi, L.M., Vecherka, V.V., Shpetnyi, M.B., Bordunova, O.H., Pavlenko, Yu.M. and Opara, V.O., 2020. Vidhodivelni ta zabiini yakosti svynei riznykh vahovykh katehorii doroshchenykh u stankakh na polimernii ta betonnii pidlozi [Fattening and slaughter qualities of pigs of different weight categories reared in machines on polymer and concrete floors]. Visnyk Sumskoho natsionalnoho ahrarnoho universytetu. Seriia «Tvarynnytstvo», issue 1 (40), pp. 1-9.

11. Khramkova, O.M., Povod, M.H., 2018. Zabiini yakosti svynei irlandskoho pokhodzhennia za riznoi predzabiinoi zhyvoi masy [Slaughter qualities of pigs of Irish origin at different pre-slaughter live weight.]. Visnyk Sumskoho natsionalnoho ahrarnoho universytetu. Seriia «Tvarynnytstvo», issue 2(34), pp. 247-250.

12. Correa, J.A, Faucitano, L., Laforest, J.P. and Rivest, J., 2006. Effects of slaughter weight on carcass composition and meat quality in pigs of two different growth rates. Meat Science, issue 72(1), pp. 91-99 DOI: 10.1016/j.meatsci.2005.06.006

13. Ellis, M. and Avery, P.J., 1994. The influence of heavy slaughter weights on growth and carcass characteristics of pigs. British Society of Animal Production, issue 5, p. 569

14. Fowler, V.R., Bichard, M., and Pease, A., 1976. Objectives in pig breeding. Animal Production, issue 23, pp. 365-387.

15. Suarez-Belloch, J., M. Sanz, M. Joy, and Latorre, M., 2013. Impact of increasing dietary energy level during the finishing period on growth performance, pork quality and fatty acid profile in heavy pigs. Meat Sci., issue 93, pp. $796-801$. doi:10.1016/j.meatsci.2012.12.006

16. Wu, F., Vierck, K.R., DeRouchey, J.M., O'Quinn, T.G., Tokach, M.D., Goodband, R.D., Dritz, S.S., and Woodworth, J.C., 2017. A review of heavy weight market pigs: status of knowledge and future needs assessment. Anim. Sci., issue 1, pp. 1-15 doi:10.2527/tas2016.0004

17. Zanfi, C. and Spanghero. M., 2012. Digestibility of diets containing whole ear corn silage for heavy pigs. Livestock Science, issue 145, pp. 287-291. dx.doi.org/10.1016/j.livsci.2012.01.009 doi:10.1016/j.livsci.2012.01.009

Mykhalko Oleksandr Hryhorovych, graduate student

Povod Mykola Hryhorovych, Doctor of Agricultural Sciences, Professor

Plechko Oksana Serhiivna, student of the Faculty of Biology and Technology

Kokhana Olena Dmytrivna, student of the Faculty of Biology and Technology

Sumy National Agrarian University (Sumy, Ukraine)

\section{Fattening and killing qualities of pigs of Irish origin with different growth intensity for fattening}

The influence of growth intensity during fattening and pre-slaughter live weight on carcass slaughter rates was studied. It was found that at the end of fattening pigs of the experimental group due to higher growth intensity during fattening reached preslaughter live weight at the age of 183 days - 128,48 kg, probably exceeding pigs with low growth intensity, which at the same age had $18,84 \mathrm{~kg}$ or $14,66 \%(p<0,001)$ lower weight. This is probably due to the higher growth intensity, which was characterized by a higher by $16,81 \mathrm{~kg}$ or $16,49 \%$ - the rate of absolute increase $(p<0,001)$, by $158,62 \mathrm{~g}$ or $16,50 \%$ - the rate of average daily gain ( $p$ $<0,001)$, and by $4,54 \%$ - an indicator of relative growth ( $p<0,001)$, which led to an earlier by 17,52 days to achieve a live weight of $100 \mathrm{~kg}$. According to the complex of fattening qualities, pigs with high growth intensity prevailed over analogues with low by 13,00 points or 32,22\%. Pigs with higher growth intensity during fattening, which were slaughtered at a pre-slaughter live weight of $130 \mathrm{~kg}$, significantly outperformed their counterparts, which were slaughtered at a weight of $110 \mathrm{~kg}$ in terms of: slaughter weight of $14,4 \mathrm{~kg}$ or $15,06 \%$, weight of chilled carcass by $14,2 \mathrm{~kg}$ or $15,15 \%$, the thickness of the fat above the 6-7 thoracic vertebrae by $4,01 \mathrm{~mm}$ or $11,43 \%$, the thickness of the fat in the withers by $3,7 \mathrm{~mm}$ or $8,89 \%$, the thickness of the fat in the buttocks $3,0 \mathrm{~mm}$ or $9,09 \%$, carcass length $3,7 \mathrm{~cm}$ or $3,64 \%$, bacon half length $6,4 \mathrm{~cm}$ or $7,18 \%$, ham weight $2,5 \mathrm{~kg}$ or $16,18 \%$, the weight of the balyk by $0,6 \mathrm{~kg}$ or $16,90 \%$ and the area of the "muscle eye" by $5,2 \mathrm{~cm}^{2}$ or $7,21 \%$. There is no significant difference in the amount of weight loss during 
cooling between the carcasses of animals of both groups. By one-way analysis of variance, a significant effect of the pre-slaughter live weight of pigs on the length of the carcass - by $44,13 \%$, the length of the bacon half - by $42,52 \%$, the thickness of the fat: in the buttocks - by $83,24 \%$, over 6-7 vertebrae - by $82,81 \%$, at the withers - by $84,04 \%$, the weight of the ham - by $67,14 \%$, the area of the "muscular eye" - at the level of $88,12 \%$. The complex index of fattening and meat qualities was higher in pigs with an average slaughter weight of $130 \mathrm{~kg}$, amounting to 188,01 points, which is 10,76 or 5,72\% higher than in pigs with an average slaughter weight of $110 \mathrm{~kg}$. It is proved that for each increase in the thickness of the fat in the withers at the pre-slaughter live weight of $110 \mathrm{~kg}$ per $1,0 \mathrm{~mm}$, the area of the "muscle eye" of the carcasses of experimental animals will also increase proportionally by $3,01 \mathrm{~cm}^{2}$. and the area of the "muscle cell" for carcasses at ante-mortem live weight of $110 \mathrm{~kg}$ suggests that there is a reserve to increase antemortem live weight both by increasing adipose tissue and by simultaneously increasing the amount of muscle tissue. However, there is a certain optimal weight limit between the slaughter weight of 110 and $130 \mathrm{~kg}$, according to which the distribution of dependence becomes inverse and further fattening and increasing the amount of fat will reduce the meat quality of carcasses, which is economically impractical.

Key words: pigs, slaughter weight, fat thickness, carcass length, ham weight, muscle eye area, growth rate

Дата надходження до редакції: 09. 11.2020 р. 